ven van verplichte en vrij te bepalen opdrachten (bewijsstukken) en van het gebruik bij selectieve (geneeskunde, Maastricht) en educatieve beoordeling (small business \& retail management, Enschede).

Hoofdstuk 6 betreft het maatwerk dat een portfolio kan bieden ten behoeve van 'zij-instromers', en de (h)Erkenning van hoe-dan-ook Verworven Competenties (EVC). Het portfolio is bij uitstek het instrument voor het krijgen van inzicht in elders verworven competenties.

De mogelijkheden van een elektronisch portfolio worden toegelicht in vier hoofdstukken. Voor de medische opleiding lijken deze niet direct interessant, maar wie introductie ervan in het onderwijsprogramma overweegt, zoals in Edinburgh is gedaan, doet er goed aan de tips in hoofdstuk 10 te lezen en zich vervolgens te verdiepen in de beschrijving van zeven jaar ervaring in de postdoctorale lerarenopleiding en de professionaliseringstrajecten voor universitaire docenten te Utrecht (hoofdstuk 7). ${ }^{2}$ Elektronische portfolio's waren meer 'to the point' dan portfolio's op papier. Zij openen ook nieuwe mogelijkheden voor onderlinge discussies, iets wat in Amsterdam wekelijks gedaan wordt in Metawerkgroepen van vijftien personen (hoofdstuk 8). Het portfolio heeft dan een 'open' gedeelte.

Hoofdstuk 11 integreert de ideeën en ervaringen van de auteurs en geeft antwoord op vragen: de aan portfolio inherente activiteiten en een "portfolio leeromgeving"; stimuleert het samenstellen van een portfolio tot reflectie? Is begeleiding daarbij nodig? Hoe is een prestatie op basis van een portfolio te beoordelen? Wat is de inhoud en de structuur van een portfolio bij gebruik als bewaker van het proces (reflectie) en van het product (beoordeling van andere bekwaamheden).

Het boek wordt afgesloten met een epiloog getiteld 'Portfolio invoeren?'

Mijn antwoord op deze vraag is: lees dan eerst dit informatieve boekje. Juist omdat het zich niet beperkt tot medisch onderwijs, waarover bijvoorbeeld in Medical Teacher al veel is te vinden.

\section{J.W. Briët}

onderwijscoördinator Geertruiden Ziekenhuis Deventer

\section{Literatuur}

1. Projectgroep G2010. Blauwdruk G2010; Herziening curriculum Geneeskunde. Groningen, Faculteit der Medische Wetenschappen; 2002.

http://coo.med.rug.nl/fmw/a30.htm.
2. Scottish Deans' Medical Group. The Scottish Doctor. Undergraduate learning outcomes and their assessment: a foundation for competent and reflective practitioners; 2002. www.scottishdoctor.org

3. Wachter J de. De portfolio-follies. Tijdschrift voor Medisch Onderwijs 2003;22(1):42.

\section{The script concordance test}

Charlin B. Standardized assessment of ill-defined clinical problems: The script concordance test [proefschrift]. Maastricht: Datawyse/ Universitaire Pers Maastricht, 114 pagina's. ISBN 9052783624.

Deze dissertatie beschrijft de script concordance test (SCT). Er wordt gerapporteerd over onderzoeken naar de theoretische en constructvaliditeit, betrouwbaarheid, de methode van scoren en de toepasbaarheid van deze test. De SCT is ontwikkeld om vaardigheid in het klinisch redeneren te beoordelen. Klinisch redeneren is onderdeel van de denk- en beslisprocessen die artsen in staat stellen adequaat te handelen, wanneer zij met een ziektegeval geconfronteerd worden. Dit wordt ook wel klinisch probleemoplossen genoemd. Klinisch probleemoplossen bestaat uit drie factoren: klinisch redeneren, domeinkennis en relevante vaardigheden, zoals sociale en medisch-technische vaardigheden. Kennis wordt veelal getoetst met meerkeuzevragen en vaardigheden met een stationsexamen (objective structured clinical examination). Maar met name het toetsen van vaardigheid in het klinisch redeneren is problematisch gebleken. Meerkeuzevragen bleken ongeschikt, patiëntencasus waren moeilijk te beoordelen, te inhoudsspecifiek, moeilijk te scoren, duur en niet efficiënt. Geschikter leek de 'key-feature approach', die vooral gericht is op de componenten die van wezenlijk belang zijn bij het oplossen van een klinisch probleem. Vanuit de cognitieve psychologie werd duidelijk dat het waardevoller is om de organisatie van kennis te meten dan alleen maar het niveau van kennis. Deze ontwikkelingen tezamen hebben geleid tot de script concordance test (SCT).

In hoofdstuk 1 wordt ingegaan op theoretische benaderingen van klinisch redeneren. De SCT is gebaseerd op de scripttheorie uit de cognitieve psychologie, die stelt dat medische kennis gestructureerd is in netwerken van kennis omtrent ziekteverschijnselen. In deze kennisnetwerken zijn verbanden opgeslagen tussen 
symptomen, ziekteverschijnselen en ziektebeelden. Symptomen en andere informatie activeren relevante kennis die richting geeft aan de selectie, interpretatie en het opslaan in het geheugen van medische informatie. Dit gebeurt via het genereren van hypothesen, het actief zoeken, organiseren en interpreteren van gegevens, hetgeen uiteindelijk uitmondt in diagnose en behandelplan. Het mechanisme wordt echter niet verder uitgelegd. Voor een gedetailleerder beschrijving van de semantische netwerktheorie zie echter bijvoorbeeld Mannes en Kintsch en Kintsch. ${ }^{1-4}$

Het proces dat door de scripttheorie beschreven wordt, is in overeenstemming met de bevindingen van diverse onderzoekers op het gebied van medische expertise. Zo kan bijvoorbeeld het schijnbare verschil tussen het voorwaarts redeneren van experts en het terugredeneren van beginnelingen verklaard worden. De auteur ziet scripts als 1) kennisstructuren die 2) (bijna) onbewust geactiveerd worden, 3 ) bestaan uit verbanden tussen klinische verschijnselen, afwijkingen en gevolgen en 4) functioneren door middel van geheugenassociatie. Dit concept heeft consequenties voor onderwijsmethoden en toetsing met betrekking tot klinisch redeneren.

In hoofdstuk 2 wordt ingegaan op de beoordeling van klinische competentie met de SCT. De SCT gaat volgens de auteur na in hoeverre de klinische kennis van studenten efficiënt georganiseerd is en leidt tot adequate klinische beslissingen. De eerste stap bij het maken van een SCT is beschrijving door medische experts van casus met daarbij relevante hypothesen, onderzoeksstrategieën, vragen die aan patiënten gesteld kunnen worden, relevant klinisch onderzoek en aanvullend onderzoek. In de test worden beknopte beschrijvingen van ziektebeelden, zogenaamde vignetten, aan de kandidaat voorgelegd in combinatie met vragen die beantwoord moeten worden op een vijfpunts Likertschaal. De vragen betreffen diagnose, onderzoek en behandeling, zijn gericht op 'keyfeatures' en de beantwoording vereist enige reflectie. De test wordt eerst door experts gemaakt en de frequenties van de door hen gegeven antwoorden bepalen de scores die studenten kunnen behalen. Hoe meer experts een bepaald antwoord geven, hoe hoger de score die dat antwoord oplevert. De auteur beweert dat op deze wijze de overeenstemming (=concordantie) tussen de scripts van experts en de scripts van studenten gemeten kan worden. Verder beweert hij dat expliciet gekeken wordt naar de overeenkomst tussen de kennisstructuren wat betreft de verbanden tussen klinische verschijnselen. Ook hier wordt dit niet verder uitgewerkt. Wel geeft hij resultaten van eerder onderzoek waaruit blijkt dat een dergelijke test differentieert tussen verschillende kennisniveaus en dat een redelijke interne consistentie $($ alfa $=0.8)$ circa vijftig items vergt. Zijn conclusie dat de test om die redenen valide en betrouwbaar is, is ons inziens gerechtvaardigd. Zijn stelling dat de organisatie van kennis getoetst wordt, is evenwel naar onze mening onvoldoende onderbouwd.

In hoofdstuk 3 en 4 wordt ingegaan op de ontwikkeling van de SCT. In hoofdstuk 3 wordt een voorloper van de SCT, de zogenaamde 'diagnostic script questionnaire' (DSQ) besproken. Met deze test kan een oordeel gevormd worden over het vermogen van de student om het effect van gegevens te wegen in relatie tot een mogelijke diagnose. De student krijgt een klinisch vignet voorgelegd. Vervolgens wordt een aantal mogelijke diagnoses gegeven, iedere keer in combinatie met een bevinding. De student moet op een zevenpunts Likertschaal aangeven welk effect de bevinding heeft op de waarschijnlijkheid van de diagnose. Deze test werd voorgelegd aan stafleden en twee groepen studenten met een verschillend kennisniveau. Er werd niet van uitgegaan dat er steeds maar één juist antwoord was. De score voor een antwoord werd bepaald door het aantal stafleden die dat antwoord gegeven hadden. De scores van de studentengroepen verschilden significant van die van de stafleden. Ons inziens is dit echter een artefact van de scoringsmethode. Een interessanter resultaat is de gevonden interactie tussen personen en items. Meer expertise ging gepaard met betere resultaten op de moeilijke items. Cronbachs alfa varieerde tussen 0.822 en 0.794. De auteur concludeert dat met de DSQ beoordeeld wordt of omvang en inhoud van de aanwezige ziektescripts een goede interpretatie van de aangeboden klinische gegevens mogelijk maken, omdat men verschillende informatie-eenheden met elkaar in verband moet brengen. Ook hier werkt hij dit niet uit. Ten slotte trekt hij uit de differentiatie tussen expertiseniveaus en de acceptabele interne consistentie de conclusie dat de DSQ een valide en betrouwbaar instrument is. Naar onze mening is dat wellicht enigszins voorbarig. De differentiatie kan immers ook een gevolg zijn van de scoringsmethode. Bovendien zijn er nog geen resultaten bekend omtrent toepassing van het instrument in andere domei- 
nen en over de test-hertestbetrouwbaarheid. De variatie in de antwoorden van de experts heeft echter wel geleid tot het inzicht dat het streven naar consensus en dus naar één goed antwoord per vraag mogelijk minder informatief is dan een scoringsmethode waarin rekening gehouden wordt met de variatie tussen experts.

Dit laatste gegeven is verder uitgewerkt in de SCT. Een onderzoek hiernaar wordt in hoofdstuk 4 besproken. Voor een SCT werden twee scoringen bepaald. Een scoring waarbij rekening gehouden werd met verschillen tussen experts (de aggregatiescoringsmethode) en een scoring waarbij door de experts per vraag één juist antwoord werd vastgesteld (de consensusscoringsmethode). De aggregatiescoringsmethode bleek beter te discrimineren tussen de verschillende expertiseniveaus. Dit is voor de auteur aanleiding om te concluderen dat deze methode een betere constructvaliditeit heeft. Ook bleek opnieuw dat de antwoorden van experts variatie vertonen. Omdat dit is verdisconteerd in de aggregatiescoringsmethode, is deze methode volgens de auteur authentieker. Cronbachs alfa van beide methoden was acceptabel. De auteur besluit dit hoofdstuk met de conclusie dat de aggregatiescoringsmethode de voorkeur verdient bij de beoordeling van complexe beslisprocessen op grond van niet-eenduidige informatie, zoals het diagnosticeren in de medische praktijk.

In hoofdstuk 5 wordt een onderzoek beschreven naar de toepassing van de SCT in verschillende culturen. De auteur toetst twee hypothesen: 1) de SCT behoudt zijn discriminerend vermogen ook als de experts afkomstig zijn uit een andere culturele en leeromgeving dan de kandidaten en 2) de kandidaten zullen hoger scoren als de experts uit dezelfde culturele en leeromgeving afkomstig zijn. De twee onderzochte culturen waren de Canadese en de Franse. De resultaten bevestigden de hypothesen. In beide culturen waren de verschillende expertiseniveaus duidelijk terug te vinden in de resultaten op de SCT. Ook hier stelt de auteur dat dit bijdraagt aan de constructvaliditeit van het instrument. In hoofdstuk 2 stelt hij echter dat de SCT expliciet kijkt naar verbanden in de kennisstructuur. De manier waarop de SCT in deze studie onderzocht is, toont dit niet afdoende aan. Een toets die verschillen in expertise meet, zegt niet automatisch iets over de kennisstructuur. Het is ons inziens dan ook de vraag in hoeverre differentiatie tussen groepen met verschillende expertiseniveaus bijdraagt aan de constructvaliditeit.
In hoofdstuk 6 wordt de rol beschreven die de SCT kan spelen in het meten van competentie binnen het domein van de radiologie. Naast vaardigheden betreffende klinisch redeneren zijn in de radiologie ook specifieke perceptuele vaardigheden vereist. De perceptuele vaardigheden zouden getoetst kunnen worden met een perceptietest en het klinisch redeneren met een SCT. De auteur toetst de hypothese dat meer training weerspiegelt wordt in hogere toetsscores. Dit werd bevestigd door de resultaten. De perceptiescores gaven grotere verschillen te zien tussen de verschillende trainingsniveaus dan de SCT scores. De verklaring hiervoor is volgens de auteur dat de toetsen verschillende componenten van radiologische competentie meten en dat perceptuele vaardigheden eerder en sneller aangeleerd worden dan de elaboratie van kennis in dit domein. Deze verklaring is plausibel, er worden echter geen alternatieve verklaringen voor dit resultaat gegeven, zoals de schaalverschillen (na transformatie) tussen de toetsen. Het zou de voorkeur verdient hebben om de regressieanalyse uit te voeren op gestandaardiseerde scores.

De auteur besluit met conclusies als antwoord op de onderzoeksvragen. Deze conclusies zijn min of meer een samenvatting van wat beschreven wordt in hoofdstuk 3 tot en met 6 .

Onze algemene conclusie met betrekking tot dit proefschrift is dat de SCT een veelbelovend instrument is met een zeer creatieve scoringsmethode. Echter, de theoretische onderbouwing blijft beperkt. Verder zijn de conclusies ten aanzien van theoretische en constructvaliditeit ons inziens te weinig empirisch onderbouwd.

Alexandra Jacobs, Universiteit Maastricht Luc Budé, Universiteit Maastricht

\section{Literatuur}

1. Mannes SM, Kintsch W. Knowledge organization and text organization. Cognition and Instruction 1987;4:91-115.

2. Kintsch W. Comprehension. A paradigm for cognition. Cambridge: Cambridge University Press; 1998.

3. Kintsch W. The role of knowledge in discourse comprehension: A construction-integration model. Psychological Review 1998;95:163-82.

4. Kintsch W. The representation of knowledge in minds and machines. International Journal of Psychology 1998;33:411-20. 